\title{
Analisis Perbandingan Persepsi Kualitas Pelayanan Dan Kepuasan Konsumen Jasa Transportasi Online Di Sumatera Selatan
}

\author{
Nyayu Khairani Putri ${ }^{1}$, Martha Rianty N. ${ }^{2}$ \\ $\mathbf{1}_{\text {Jurusan Manajemen, Universitas Tridinanti }}$ \\ Palembang \\ Email: nyayukhairani@yahoo.com \\ 2Jurusan Akuntansi, Universitas Tridinanti Palembang \\ Email : martharianty@univ- \\ tridinanti.ac.id
}

\begin{abstract}
:
The purpose of this research is to compare perceptions of service quality and consumer satisfaction of online transportation services in South Sumatra, with a Case Study of Go-Jek Consumers, Go-Ride Service Users and Grab Consumers, Grabbike Service Users. This research is a comparative study. Information about the research is obtained from data collection techniques that have been carried out on research subjects, namely users of Go-Jek (GoRide) and Grab (Grabbike). The population in this study ware people who had used Go-Jek and Grab, while the study sample was 100 respondents. The Paired Sample T-Test is a data analysis technique in this study using the IBM SPSS Statistics 22 application.The results showed that there was no significant difference between Go-Ride Service Quality and Grabbike Service Quality, and there was a significant difference between Go-Ride Consumer Satisfaction and Grabbike Consumer Satisfaction.
\end{abstract}

Keywords: Service Quality and Customer Satisfaction

Penelitian ini bertujuan untuk mengetahui perbandingan persepsi kualitas pelayanan dan kepuasan konsumen jasa trasnportasi online di Sumatera Selatan, dengan Studi Kasus Pada Konsumen Go-Jek Pengguna Layanan Go-Ride Dan Konsumen Grab Pengguna Layanan Grabbike. Penelitian ini merupakan penelitian komparatif.Informasi mengenai penelitian didapatkan dari teknik-teknik pengumpulan data yang telah dilakukan terhadap subyek penelitian yaitu pengguna Go-Jek (GoRide) dan Grab(Grabbike). Populasi dalam penelitian ini adalah orang yang pernah menggunakan Go-Jek dan Grab, sedangkan sampel penelitian adalah 100 responden. Uji Paired Sample T-Test adalah teknik analisis data dalam penelitian ini dengan menggunakan aplikasi IBM SPSS Statistik 22. Hasil penelitian menunjukan tidak terdapat perbedaan yang signifikan antara Kualitas Pelayanan Go-Ride dan Kualitas Pelayanan Grabbike, dan terdapat perbedaan yang signifikan antara Kepuasan Konsumen Go-Ride dan Kepuasan Konsumen Grabbike.

Kata kunci: Kualitas Pelayanan dan Kepuasan Konsumen 


\section{Pendahuluan}

Perkembangan teknologi internet yang cukup pesat memberikan perubahan sosial pada masyarakat. Banyak bisnis mulai bermunculan dengan memanfaatkan perkembangan teknologi informasi dimana banyak jasa transportasi yang memanfaatkan kemajuan teknologi yang merupakan jasa transportasi online. Salah satunya adalah kemunculan bisnis penyedia layanan jasa berbasis aplikasi. Salah satu yang menjadi trend saat ini adalah jasa transportasi online seperti aplikasi Gojek dan Grab yang banyak dinikmati masyarakat di Indonesia selain sebagai penyedia jasa transportasi online, Gojek dan Grab juga menyediakan berbagai macam jasa layanan online yang mereka sediakan didalam aplikasi tersebut bertujuan untuk mempermudah segala aktivitas -aktivitas manusia yang dilakukan sehari - hari akan tetapi jasa layanan yang sering digunakan pada aplikasi tersebut ialah Go-ride dan Grabbike. Semakin menjamurnya penikmat dari jasa transportasi online di Indonesia dengan alasan masing - masing yang berdampak pada kualitas pelayanan dan kepuasan konsumen terhadap perbandingan aplikasi Gojek dan Grab.

Kota Palembang menjadi salah satu pilihan kota yang memiliki potensi yang besar dalam pengembangan bisnis transportasi. Kota Palembang merupakan salah satu kota yang memiliki kegiatan yang padat sehingga tidak lepas dari kegiatan transportasi sehati-hari khususnya angkutan masyarakat. Pada saat ini transportasi umum yang paling menonjol di Palembang adalah onjek online Gojek dan Grab. Hadirnya Gojek dan Grab di Kota Palembang memberikan kemudahan bagi masyarakat Kota Palembang, karena masyarakat umumnya mendapatkan transportasi dengan cepat dan selalu bisa dating ke tempat yang mereka inginkan tanpa harus pergi ke jalan raya atau tempat umum pangkalan atau terminal angkutan masyarakat Kota Palembang.

Gojek dan Grab merupakan tranportasi online yang paling dikenal dalam pasar Indonesia. Kedua ojek inline tersebut dengan memiliki fitur layanan yang hampir mirip dan tariff harga yang sama-sama bersaing. Dalam kategori Aplikasi Transportasi, tercatat Go-Jek lebih banyak digunakan oleh 70,4\% responden dibanding Grab 45,7\%. Riset Alvara menampilkan data bahwa minat konsumen terhadap Go-Jek berkaitan dengan kualitas layanan yakni Mudah Digunakan (13,9\%), Lebih Cepat (11,2\%), dan Aplikasi Termurah (8,8\%),( www.economy.okezone.com, diakses tanggal 23 September 2019).

Kualitas pelayanan merupakan kunci untuk mencapai kesuksesan dalam suatu perusahaan jasa transportasi online. Kualitas pelayanan yang baik dapat dilihat dari kemampuan produsen dalam memenuhi harapan konsumen secara konsisten, dan dapat dikatakan memuaskan apabila layanan yang dirasakan sama atau melebihi kualitas pelayanan yang diharapkan konsumen. Harapan konsumen dapat tercermin pada palayanan yang baik, ramah tamah, ketepatan waktu, sopan santun, dan kecepatan merupakan nilai penting yang diharapkan oleh konsumen. Dari kepuasan konsumen maka secara tidak langsung akan mendorong konsumen tersebut untuk merekomendasikan suatu perusahaan atau aplikasi tersebut dengan masyarakat, sehingga secara tidak langsung akan meningkatkan citra perusahaan atau aplikasi 
tersebut dimata masyarakat atau calon konsumen lainnya. Oleh karena itu, kualitas pelayanan harus menjadi fokus utama perhatian perusahaan karena dapat menciptakan kepuasan konsumen.

Saat ini banyak perusahaan yang semakin memahami arti penting dari kepuasan konsumen dan menjalankan strategi guna memberikan kepuasan bagi konsumennya. Menurut Kotler dan Keller (2016) Kepuasan Konsumen adalah perasaan senang atau kecewa seseorang yang timbul karena membandingkan kinerja yang dipersepsikan produk (hasil) terhadap ekspektasi mereka. Jika kinerja sesuai ekspektasi, pelanggan akan puas. Jika kinerja tidak sesuai ekspektasi, pelanggan tidak puas.

Berdasarkan temuan tersebut peneliti tertarik untuk melakukan penelitian tentang "Analisis Perbandingan Persepsi Kualitas Pelayanan Dan Kepuasan Konsumen Jasa Transportasi Online Di Sumatera Selatan (Studi Kasus Pada Konsumen Go-Jek Pengguna Layanan Go-Ride Dan Konsumen Grab Pengguna Layanan Grabbike).

\section{Landasan Teori Pemasaran}

\section{a. Pengertian Pemasaran}

Menurut Kotler dan Armstrong (2016:29) "Marketing is the process by which companies create value for customers and build strong customers relationship in order to capture value from customers in return." Artinya pemasaran adalah proses dimana perusahaan menciptakan nilai bagi pelanggan dan membangun hubungan pelanggan yang kuat untuk mendapatkan nilai dari pelanggan sebagai imbalan.

b. Manajemen Pemasaran

Menurut Kotler dan Keller (2016:27), "Marketing management as the art and science of choosing target markets and getting, keeping, and growing customers through creating, delivering, and communicating superior customer value."Arti dari definisi tersebut, manajemen pemasaran sebagai seni dan ilmu memilih pasar sasaran dan mendapatkan, mempertahankan, serta meningkatkan jumlah pelanggan dengan menciptakan, menghantarkan, dan mengomunikasikan nilai pelanggan yang unggul.

\section{c. Bauran Pemasaran}

Menurut Lupiyoadi (2013:92), bauran pemasaran merupakan perangkat/alat bagi pemasar yang terdiri atas berbagai unsur program pemasaran yang perlu dipertimbangkan agar implementasi strategi pemasaran dan penentuan posisi yang ditetapkan dapat berjalan dengan sukses. Bauran pemasaran pada produk barangyang kita kenal selama ini berbeda dengan bauran pemasaran untuk produk jasa. Bauran pemasaran produk barang mencakup 4P, yaitu produk, harga, lokasi/tempat dan promosi. Sementara untuk produk jasa ada tiga unsur tambahan, yaitu orang atau sumber daya manusia (SDM), proses, dan layanan pelanggan. 
Jasa

Menurut Kotler dalam Lupiyoadi (2013:7), jasa adalah setiap tindakan dan kegiatan yang ditawarkan oleh suatu pihak ke pihak lain, pada dasarnya tidak berwujud dan tidak mengakibatkan perpindahan kepemilikan apapun. Produksi jasa mungkin berkaitan dengan produk fisik atau tidak. Sedangkan menurut Zethalm dan Bitner dalam Lupiyoadi (2013:7), jasa pada dasarnya merupakan semua aktifitas ekonomi yang hasilnya tidak merupakan produk dalam bentuk fisik atau kontruksi, yang umumnya dikomsumsi pada saat yang sama dengan waktu dihasilkan dan memberikan nilai tambah (misalnya, kenyamanan, hiburan, kesenangan, atau kesehatan) atau pemecahan atas masalah yang dihadapi konsumen.

\section{Transportasi}

Menurut Salim (2013:2) transportasi adalah kegiatan pemindahan barang (muatan) dan penumpang dari suatu tempat ke tempat lain. Dalam transportasi ada dua unsur yang terpenting yaitu pemindahan / pergerakan dan secara fisik mengubah tempat dari barang (komoditi) dan penumpang ke tempat lain.

\section{Kualitas Pelayanan}

Menurut Lewis dan Booms (1983) yang dikutip oleh Tjiptono (2011:180) kualitas jasa sebagai ukuran seberapa bagus tingkat layanan yang diberikan mampu sesuai dengan ekspetasi konsumen. Berdasarkan definisi ini, kualitas layanan ditentukan oleh kemampuan perusahaan memenuhi kebutuhan dan keinginan konsumen sesuai dengan ekspetasi konsumen. Tjiptono dalam Sunyoto (2012) mengatakan bahwa kualitas atau mutu dalam industri jasa pelayanan adalah suatu penyajian produk atau jasa sesuai ukuran yang berlaku di tempat produk tersebut diadakan dan penyampaiannya setidaknya sama dengan yang diingkan dan diharapkan oleh konsumen. Berdasarkan beberapa definisi diatas penulis menyimpulkan bahwa kualitas pelayanan merupakan suatu penyajian produk atau jasa yang sesuai dengan standar perusahaan dan diupayakan dalam penyampaian produk dan jasa tersebut sama dengan apa yang diharapkan tamu restoran atau melebihi ekspetasi tamu.

Menurut Lupiyoadi (2013:180), menyederhanakan sepuluh dimensi menjadi lima pokok yang dikenal dengan SERQUAL (servicequality) yang terdiri dari:

1. Bukti fisik (Tangibles) yaitu kemampuan suatu perusahaan dalam menunjukkan eksistensinya kepada pihak eksternal. Penampilan dan kemampuan sarana dan prasarana fisik perusahaan yang dapat diandalkan serta keadaan lingkungan sekitarnya merupakan salah satu cara perusahaan jasa dalam menyajikan kualitas layanan terhadap pelanggan. Diantaranya meliputi fasilitas fisik (gedung, buku, rak buku, meja dan kursi, dan lain sebagainya), teknologi (peralatan dan perlengkapan yang dipergunakan), serta penampilan pegawai.

2. Kehandalan (Reability) adalah kemampuan perusahaan memberikan pelayanan sesuai dengan apa yang dijanjikan secara akurat dan terpercaya, kinerja harus 
sesuai dengan harapan pelanggan yang tercermin dari ketepatan waktu, pelayanan yang sama untuk semua pelanggan tanpa kesalahan, sikap simpatik dan akurasi yang tinggi.

3. Daya tanggap (Responsiveness) adalah kemauan untuk membantu pelanggan dan memberikan jasa dengan cepat dan tepat dengan penyampaian informasi yang jelas. Mengabaikan dan membiarkan pelanggan menunggu tanpa alasan yang jelas menyebabkan persepsi yang negative dalam kualitas pelayanan.

4. Jaminan (Assurance) adalah pengetahuan, kesopan-santunan dan kemampuan para pegawai perusahaan untuk menumbuhkan rasa percaya para pelanggan kepada perusahaan. hal ini meliputi beberapa komponen, antara lain:

5. Empati (Empathy) yaitu memberikan perhatian yang tulus dan bersifat individual atau pribadi yang diberikan kepada pelanggan dengan berupaya memahami keinginan konsumen dimana suatu perusahaan diharapkan memiliki suatu pengertian dan pengetahuan tentang pelanggan, memahami kebutuhan pelanggan secara spesifik, serta memiliki waktu pengoperasian yang nyaman bagi pelanggan.

\section{Dimensi Kualitas Pelayanan}

Berikut lima dimensi dalam menentukan kualitas jasa menurut Zeithaml (1996: 38), adalah : (a) Reliability, (b) Responsiveness, (c) Assurance, (d) Emphaty, dan (e)Tangibles.

\section{Kepuasan Konsumen}

Menurut Kotler dan Keller (2016), “Kepuasan adalah perasaan senang atau kecewa seseorang yang muncul setelah membandingkan kinerja (hasil) produk yang dipikirkan terhadap kinerja yang diharapkan". Menurut Tjiptono (2011:301), kepuasan konsumen adalah situasi yang ditunjukkan oleh konsumen ketika mereka menyadari bahwa kebutuhan dan keinginannya sesuai dengan yang diharapkan serta terpenuhi secara baik. Sedangkan menurut jurnal Bachtiar (2011), kepuasan konsumen merupakan perasaan positif konsumen yang berhubungan dengan produk / jasa selama menggunakan atau setelah menggunakan jasa atau produk.

Tidak ada manfaatnya jika perusahaan memberikan jasa yang bagus kalau tidak dapat menciptakan dan mempertahankan konsumen. Karena pada dasarnya tujuan suatu bisnis adalah untuk menciptakan kepuasan kepada para pelanggannya.Untuk membuat para konsumen merasa puas, manajemen perusahaan harus mengetahui halhal yang menyebabkan terciptanya kepuasan konsumen. Adanya kepuasan konsumen membuat hubungan baik antara konsumen dan perusahaan. Mardikawati dan Farida (2013: 64-75) berpendapat bahwa indikator kepuasan konsumen jasa transportasi yaitu :

1. Layanan yang diharapkan sesuai, dimana pendapat konsumen mengenai kesesuaian kualitas jasa yang diberikan dengan harapan konsumen. 
2. Harga yang dibayarkan sesuai dengan kualitas layanan, dalam hal ini berkaitan dengan pendapat konsumen mengenai layanan yang diberikan telah sesuai dengan harga yang diberikan.

3. Kepuasan konsumen terhadap layanan yang diberikan, dalam hal ini berkaitan dengan pendapat konsumen mengenai kualitas layanan yang diberikan apakah telah memuaskan konsumen.Perusahaan dapat mengetahui kepuasan dari para konsumennya melalui sikap yang diberikan oleh konsumen seperti keluhan dan lainnya mengenai jasa yang diberikan perusahaan sehingga dapat menjadi masukan bagi perusahaan dan motivasi untuk meningkatkan kepuasan konsumen. Sikap konsumen tersebut merupakan kunci bagi perusahaan untuk dapat mengetahui kinerja dari perusahaan.

\section{Pengukuran Kepuasan Pelanggan}

Kotler, et al (1996) dalam Tjiptono (2011) mengidentifikasi empat metode untuk mengukur kepuasan pelanggan, yaitu sebagai berikut: (1) Sistem Keluhan dan Saran, (2) Ghost Shopping, (3) Lost Customer Analysis, (4) Survei kepuasan pelanggan. Sementara itu, kepuasaan pelanggan dalam penelitian ini diukur dengan menggunakan 3 indikator dari Consuegra (2007) yang meliputi: kesesuaian harapan, persepsi kinerja, dan penilaian pelanggan.

\section{Kerangka Penelitian}

Berdasarkan uraian sebelumnya dapat digambarkan dalam kerangka penelitian sebagai berikut:

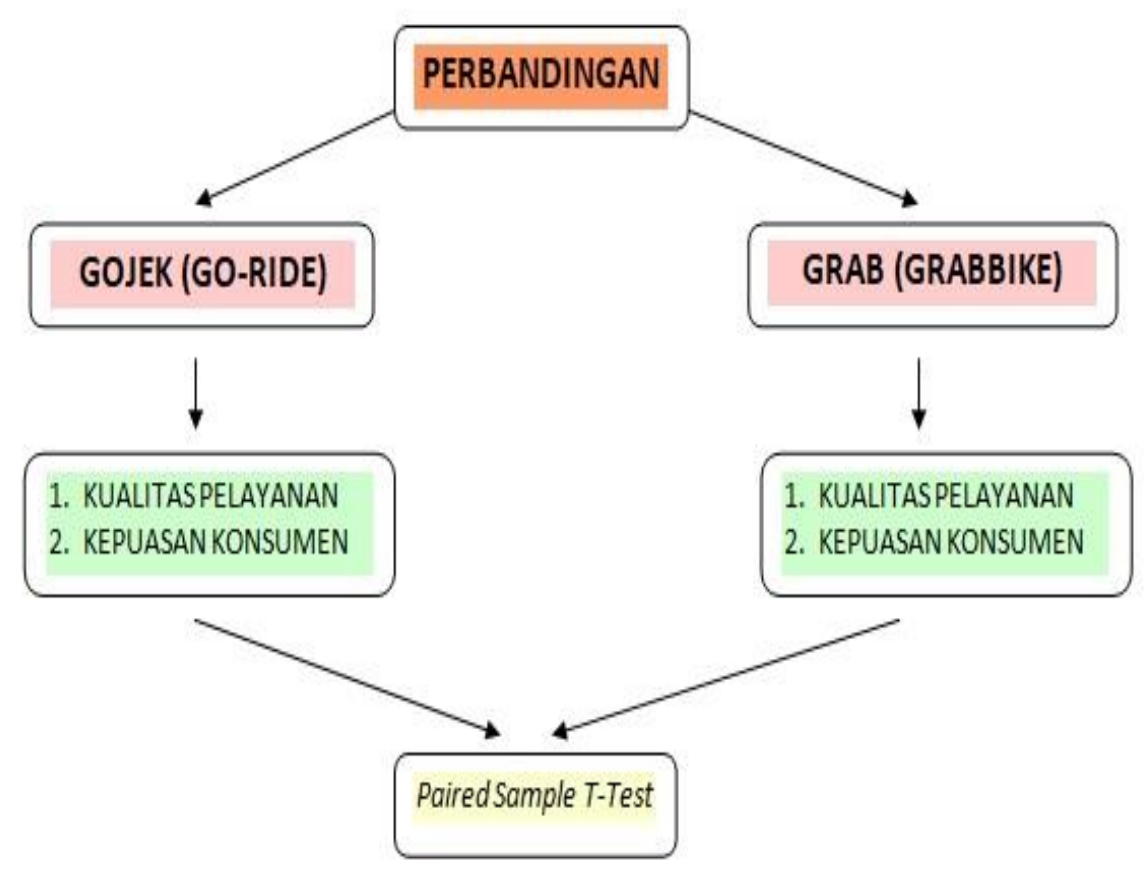

Gambar 1. Kerangka Penelitian 
Penelitian Terdahulu yang dapat dijadikan rujukan penelitian ini yaitu :

a. Lumintang Intan Sintya, dkk (2018). Hasil penelitian ini menunjukkan bahwa ada pengaruh harga dan kualitas layanan terhadap kepuasan pelanggan. Untuk bisa bertahan dalam persaingan Gojek online sebaiknya melakukan evaluasi sejauh mana harga yang ditawarkan sesuai dengan pangsa pasar.

b. Zulmianita Putuhena \& Andi Faisal Bahari (2019). Berdasarkan hasil penelitian dan pembahasan yang telah dikemukakan sebelumnya dapat ditarik beberapa kesimpulan sebagai berikut, (1) Dimensi kualitas layanan jasa transportasi online (GrabCar) yaitu variabel bukti fisik (tangibles) tidak berpengaruh signifikan terhadap kepuasan konsumen, (2) Dimensi kualitas layanan angkutan umum berbasis online (GrabCar) yaitu variabel kehandalan (reliability) berpengaruh signifikan terhadap kepuasan konsumen, (3) Dimensi kualitas layanan angkutan umum berbasis online (GrabCar) yaitu ketanggapan (responsiveness) berpengaruh signifikan terhadap kepuasan konsume dan (4) Dimensi kualitas layanan angkutan umum berbasis online (GrabCar) yaitu jaminan (assurance) tidak berpengaruh signifikan terhadap kepuasan konsumen.

\section{Metodologi Penelitian \\ Lokasi Penelitian}

Adapun lokasi dalam penelitian ini dilakukan di Kota Palembang, Sumatera Selatan.

\section{Desain Penelitian}

a. Jenis Penelitian

Jenis penelitian yang digunakan adalah penelitian komperatif. Penelitian komperatif adalah penelitian yang bersifat untuk membandingkan persamaan dan perbedaan dua atau lebih fakta-fakta dan sifat-sifat objek yang diteliti berdasarkan kerangka pemikiran tertentu.

b. Populasi dan Sampel

Populasi dalam penelitian ini adalah masyarakat umum yang pernah menggunakan jasa transportasi online secara aktif di Palembang. Sampel dari penelitian ini adalah konsumen masyarakat umum yang pernah menggunakan kedua jasa transportasi Go-ride dan Grabbike di Kota Palembang, karena peneliti tidak mengetahui jumlah pasti dari populasi konsumen Go-ride dan Grabbike di Kota Palembang, maka penulis menggunakan rumus untuk mencari jumlah pasti sampel dalam dari populasi, yaitu: 


$$
\begin{aligned}
& \mathrm{n}=\frac{\mathrm{Z}^{2}}{4 /(\mathrm{Moe})^{2}} \\
& \mathrm{n}=\frac{(1,96)^{2}}{4 /(10 \%)^{2}} \\
& \mathrm{n}=96,04
\end{aligned}
$$

Keterangan :

$\mathrm{n}$ = jumlah sampel

$\mathrm{N}=$ tingkat keyakinan yang dibutuhkan dalam penentuan sampel $(95 \%=1,96)$

Moe = Margin of Error yaitu tingkat kesalahan maksimum yang masih bisa ditolerir (ditentukan 10\%)

Berdasarkan hasil perhitungan di atas, diketahui jumlah sampel sebesar 96 responden atau dibulatkan menjadi 100 responden.

\begin{tabular}{|c|c|c|c|}
\hline NO. & VARIABEL & DEFINISI OPERASIONAL VARIABEL & INDIKATOR \\
\hline \multirow[t]{6}{*}{1.} & Kualitas & \multirow{6}{*}{$\begin{array}{l}\text { Menurut Lewis dan Booms (1983) yang dikutip oleh } \\
\text { Tjiptono (2011:180) kualitas jasa sebagai ukuran } \\
\text { seberapa bagus tingkat layanan yang diberikan } \\
\text { mampu sesuai dengan ekspetasi konsumen. Kualitas } \\
\text { pelayanan merupakan suatu penyajian produk atau } \\
\text { jasa yang sesuai dengan standar perusahaan dan } \\
\text { diupayakan dalam penyampaian produk dan jasa } \\
\text { tersebut sama dengan apa yang diharapkan tamu } \\
\text { restoran atau melebihi ekspetasi tamu. }\end{array}$} & Fasilitas Fisik \\
\hline & \multirow{5}{*}{ Pelayanan $\left(\mathrm{X}_{1}\right)$} & & (Tangible) \\
\hline & & & $\begin{array}{l}\text { Keandalan } \\
\text { (Reliability) }\end{array}$ \\
\hline & & & $\begin{array}{l}\text { Daya Tanggap } \\
\text { (Responsiveness) }\end{array}$ \\
\hline & & & $\begin{array}{l}\text { Jaminan } \\
\text { (Assurance) }\end{array}$ \\
\hline & & & Empati (Empathy) \\
\hline \multirow[t]{3}{*}{2.} & \multirow[t]{3}{*}{$\begin{array}{l}\text { Kepuasan } \\
\text { Konsumen }\left(\mathrm{X}_{2}\right)\end{array}$} & \multirow{3}{*}{$\begin{array}{l}\text { Menurut Tjiptono (2011:301), kepuasan konsumen } \\
\text { adalah situasi yang ditunjukkan oleh konsumen } \\
\text { ketika mereka menyadari bahwa kebutuhan dan } \\
\text { keinginannya sesuai dengan yang diharapkan serta } \\
\text { terpenuhi secara baik }\end{array}$} & $\begin{array}{l}\text { Konfirmasi } \\
\text { kualitas pelayanan } \\
\text { dengan yang } \\
\text { diharapkan. }\end{array}$ \\
\hline & & & $\begin{array}{l}\text { Kesesuaian } \\
\text { harga/tariff yang } \\
\text { dibayarkan }\end{array}$ \\
\hline & & & $\begin{array}{l}\text { Kepuasan } \\
\text { pelanggan } \\
\text { terhadap layanan } \\
\text { yang ditawarkan. }\end{array}$ \\
\hline
\end{tabular}

\section{Definisi Operasional Variabel}

\section{Tabel 1. Definisi Operasional Variabel}

\section{Model Analisis Data}

Model analisis data yang digunakan dalam penelitian ini adalah sebagai berikut:

a. Analisis Kualitatif

Analisis Kualitatif yang digunakan pada penelitian ini yaitu dengan membandingkan tabel hasil dari kuesioner dan wawancara, lalu diberikan interpestasi untuk menjelaskan semua hasil analisis data. Khususnya yang berkaitan dengan kualitas pelayanan dan kepuasan konsumen Gojek dan Grab di 
Sumatera Selatan

b. Analisis Kuantitatif

Analisis Kuantitatif dalam penelitian ini dinyatakan dalam bentuk angka-angka dan dihitung dengan menggunakan rumus statistik. Data dihitung berdasarkan hasil daftar pernyataan berupa pelanggan Gojek dan Grab, dimana jawaban responden dinilai sebagai berikut :

Penilaian kualitas pelayanan dan kepuasan konsumen pada Gojek dan Grab di Sumatera Selatan. Skor terbagi dalam kategori sebagai berikut:

1 Jawaban sangat setuju di beri bobot : 5

2 Jawaban setuju diberi bobot $\quad: 4$

3 Jawaban Netral diberi bobot : 3

4 Jawaban tidak setuju diberi bobot $\quad: 2$

5 Jawaban sangat tidak setuju diberi bobot $\quad: 1$

\section{Teknik Analisis Data}

a. Uji Validitas

Uji validitas digunakan untuk mengukur sah atau tidaknya suatu kuesioner. Suatu kuesioner dikatakan sah jika pertanyaan pada kuesioner mampu mengungkapkan sesuatu yang akan diukur oleh kuesioner tersebut. Uji validitas dilakukan dengan membandingkan nilai $r$ hitung (untuk setiap butir dapat dilihat pada kolom corrected item-total correlations) dengan $r$ tabel untuk degree of freedom $(d f)=\mathrm{n}-\mathrm{k}$, dalam hal ini $\mathrm{n}$ adalah jumlah sampel dan $\mathrm{k}$ adalah jumlah item. Jika $r$ hitung $>r$ tabel, maka pertanyaan tersebut dikatakan valid (Ghozali,2011).

b. Uji Realibilitas

Uji Reliabilitas merupakan alat untuk mengukur suatu kuesioner yang merupakan indikator dari variabel atau konstruk. Suatu koesioner dikatakan reliable atau handal jika jawaban seseorang terhadap pertanyaan konsisten atau stabil dari waktu ke waktu. SPSS memberikan fasilitas untuk mengukur reliabilitas dengan uji statistik Cronbach Alpha $(\alpha)$. Suatu variabel dikatakan reliabel jika memberikan nilai $\alpha>0,60$ Nunnally, dalam (Ghozali, 2011).

c. Uji Independent Sample T-Test (Uji Beda)

Uji beda untuk jenis penelitian yang menghasilkan data berskala interval, pada umumnya dimaksudkan untuk menguji Perbandingan rata-rata hitung diantara kelompok-kelompok tertentu yang memiliki persyaratan tertentu yang diteliti. Jika kelompok sampel yang ingin diuji Perbandingan rata-rata hitungnya hanya terdiri dari dua kelompok, teknik statistik yang dipergunakan pada umumnya adalah teknik t-test. Untuk menguji dua kelompok yang subjeknya berbeda, namun dikenakan perlakukan yang sama, maka teknik yang digunakan adalah 
t-test untuk sampel bebas. (Nurgiyantoro, 2013).

Uji beda Variabel Kualitas Pelayanan dan Kepuasan Konsumen :

- Kualitas Pelayanan GoRide dan Grabbike

$\mathrm{H}_{0}$ : Tidak ada perbedaan persepsi konsumen terhadap kualitas pelayanan pada pengguna transportasi Go-Ride dan Grabbike di Sematera Selatan

$\mathrm{H}_{1}$ : Ada perbedaan persepsi konsumen terhadap kualitas pelayanan pada pengguna transportasi Go-Ride dan Grabbike di Sematera Selatan

- Kepuasan Konsumen GoRide dan Grabbike

$\mathrm{H}_{0}$ : Tidak ada perbedaan persepsi konsumen terhadap kepuasan konsumen pada pengguna transportasi Go-Ride dan Grabbike di Sematera Selatan

$\mathrm{H}_{1}$ : Ada perbedaan persepsi konsumen terhadap kepuasan konsumen pada pengguna transportasi Go-Ride dan Grabbike di Sematera Selatan

d. Dasar pengambilan keputusan dengan melihat angka probabilitas dengan ketentuan :

1. Probabilitas $>0,05$, maka Ho diterima

2. Probabilitas $<0,05$, maka Ho ditolak.

\section{Teknik Pengumpulan Data}

\section{Jenis Data}

Data yang digunakan dikumpulkan adalah data primer dan data sekunder.

a. Data Primer

Yaitu data yang langsung di peroleh dari sumbernya yaitu pelanggan Gojek dan Grab di Sumatera Selatan. Data ini merupakan data mentah dari hasil wawancara, kuesioner dan dokumentasi yang kemudian diolah dan disimpulkan oleh peneliti.

b. Data Sekunder

Data Sekunder merupakan data yang diperoleh secara tidak langsung dari kantor Gojek dan Grab dalam bentuk literatur-literatur yang ada di buku-buku yang ada hubungannya dengan penelitian ini.

\section{Metode Pengumpulan Data}

Data yang diperlukan dalam penelitian ini diambil dengan menggunakan metode:

a. Kuisioner

Penggunaan kuesioner ini dimaksudkan untuk memperoleh data tentang kualitas pelayanan dan kepuasan konsumen Go-ride dan Grabbike di Kota Palembang. 


\section{b. Wawancara}

Dengan mengadakan tanya jawab langsung dengan responden yang dijadikan sampel dalam penulisan ini, yang bertujuan untuk mengetahui Perbandingan kualitas pelayanan dan kepuasan konsumen Gojek dan Grab di Sumatera Selatan

c. Dokumentasi

Yaitu pengambilan data yang diperoleh melalui dokumen-dokumen. Dalam hal ini peneliti mengumpulkan data-data yang berupa, catatan, arsip, dan sebagainya yang berhubungan dengan hal-hal yang berkaitan dengan kualitas pelayanan dan kepuasan konsumen Gojek dan Grab di Sumatera Selatan

\section{Hasil Penelitian Dan Pembahasan Analisis Deskriptif}

Tabel 1. Hasil Analisis Deskriptif Kualitas Pelayanan Go-Ride dan Grabbike

\begin{tabular}{|c|c|c|c|c|c|c|}
\hline DIMENSI & No & INDIKATOR & $\begin{array}{c}\text { Skor } \\
\text { Dimensi } \\
\text { Go-Ride }\end{array}$ & $\begin{array}{l}\text { Mean } \\
\text { Go-Ride }\end{array}$ & $\begin{array}{c}\text { Skor } \\
\text { Dimensi } \\
\text { Grabbike }\end{array}$ & $\begin{array}{l}\text { Mean } \\
\text { Grabbike }\end{array}$ \\
\hline \multirow{6}{*}{$\begin{array}{c}\text { Kualitas } \\
\text { Pelayanan : } \\
\text { Fasilitas Fisik } \\
\text { (Tangible) }\end{array}$} & 1 & $\begin{array}{l}\text { Driver memberikan helm dan } \\
\text { masker }\end{array}$ & \multirow{6}{*}{3.726667} & 3.72 & \multirow{6}{*}{3.648333} & 3.62 \\
\hline & 2 & $\begin{array}{l}\text { Driver berpakaian dengan rapi saat } \\
\text { melakukan pelayanan }\end{array}$ & & 3.73 & & 3.62 \\
\hline & 3 & $\begin{array}{l}\text { Jaket yang digunakan driver tidak } \\
\text { berbau }\end{array}$ & & 3.72 & & 3.59 \\
\hline & 4 & Penampilan driver bersih & & 3.65 & & 3.67 \\
\hline & 5 & $\begin{array}{l}\text { Driver menggunakan sepatu saat } \\
\text { melakukan pelayanan }\end{array}$ & & 3.76 & & 3.70 \\
\hline & 6 & $\begin{array}{l}\text { Kendaraan yang digunakan layak } \\
\text { pakai }\end{array}$ & & 3.78 & & 3.69 \\
\hline \multirow{7}{*}{$\begin{array}{l}\text { Kualitas } \\
\text { Pelayanan : } \\
\text { Keandalan } \\
\text { (Reliability) }\end{array}$} & 1 & $\begin{array}{l}\text { Driver Go-ride/Grabbike selalu } \\
\text { tersedia pada saat dibutuhkan }\end{array}$ & \multirow{7}{*}{3.712857} & 3.79 & \multirow{7}{*}{3.662857} & 3.65 \\
\hline & 2 & $\begin{array}{l}\text { Driver memberikan layanan tepat } \\
\text { waktu }\end{array}$ & & 3.74 & & 3.65 \\
\hline & 3 & $\begin{array}{l}\text { Ada pemberitahuan dengan jelas, } \\
\text { apabila terjadi keterlambatan }\end{array}$ & & 3.68 & & 3.59 \\
\hline & 4 & $\begin{array}{l}\text { Driver mengemudi dengan menaati } \\
\text { peraturan lalu lintas }\end{array}$ & & 3.74 & & 3.71 \\
\hline & 5 & $\begin{array}{l}\text { Driver mengenakan harga sesuai } \\
\text { dengan tarif yang tertera di aplikasi }\end{array}$ & & 3.70 & & 3.67 \\
\hline & 6 & $\begin{array}{l}\text { Driver mengantarkan konsumen ke } \\
\text { tempat tujuan dengan akurat }\end{array}$ & & 3.71 & & 3.77 \\
\hline & 7 & Beroperasi selama 24 jam & & 3.63 & & 3.60 \\
\hline \multirow{3}{*}{$\begin{array}{c}\text { Kualitas } \\
\text { Pelayanan : } \\
\text { Daya Tanggap } \\
\text { (Responsivenes } \\
\text { s) }\end{array}$} & 1 & $\begin{array}{l}\text { Driver mengonfirmasi order dengan } \\
\text { menghubungi konsumen, untuk } \\
\text { memastikan pemesanan dan tempat. }\end{array}$ & \multirow{3}{*}{3.666667} & 3.60 & \multirow{3}{*}{3.703333} & 3.76 \\
\hline & 2 & $\begin{array}{l}\text { Driver segera datang setelah } \\
\text { menerima pesanan melalui aplikasi. }\end{array}$ & & 3.72 & & 3.62 \\
\hline & 3 & $\begin{array}{l}\text { Driver cepat dalam menanggapi } \\
\text { keluhan pelanggan. }\end{array}$ & & 3.68 & & 3.73 \\
\hline \multirow{3}{*}{$\begin{array}{c}\text { Kualitas } \\
\text { Pelayanan : } \\
\text { Jaminan } \\
\text { (Assurance) }\end{array}$} & 1 & $\begin{array}{l}\text { Driver dapat mengemudikan sepeda } \\
\text { motor dengan baik. }\end{array}$ & \multirow{3}{*}{3.756667} & 3.74 & \multirow{3}{*}{3.716667} & 3.67 \\
\hline & 2 & $\begin{array}{l}\text { Driver mempunyai pengetahuan } \\
\text { mengenai informasi jalan/alamat } \\
\text { yang akan dituju }\end{array}$ & & 3.70 & & 3.71 \\
\hline & 3 & $\begin{array}{l}\text { Tersedia layanan pengaduan pada } \\
\text { aplikasi }\end{array}$ & & 3.83 & & 3.77 \\
\hline $\begin{array}{c}\text { Kualitas } \\
\text { Pelayanan : } \\
\text { Empati } \\
\end{array}$ & 1 & $\begin{array}{l}\text { Driver memberitahukan tentang } \\
\text { penggunaan helm yang benar } \\
\text { kepada konsumen. }\end{array}$ & 3.756667 & 3.76 & 3.683333 & 3.72 \\
\hline
\end{tabular}




\begin{tabular}{|c|c|c|c|c|c|c|}
\hline \multirow[t]{2}{*}{ (Empathy) } & 2 & $\begin{array}{l}\text { Driver membantu pelanggan dalam } \\
\text { mengangkat barang. }\end{array}$ & & 3.70 & & 3.64 \\
\hline & 3 & $\begin{array}{l}\text { Driver sopan dan ramah dalam } \\
\text { melakukan pelayanan. }\end{array}$ & & 3.81 & & 3.69 \\
\hline \multirow{3}{*}{$\begin{array}{l}\text { Kepuasan } \\
\text { Konsumen }\end{array}$} & 1 & $\begin{array}{l}\text { Saya merasa kualitas pelayanan } \\
\text { yang diberikan sesuai dengan apa } \\
\text { yang saya harapkan. }\end{array}$ & \multirow{3}{*}{4.17} & 4.09 & \multirow{3}{*}{3.813333} & 3.78 \\
\hline & 2 & $\begin{array}{l}\text { Saya merasa manfaat yang saya } \\
\text { peroleh sesuai dengan tarif harga } \\
\text { yang saya bayarkan pada Go-ride/ } \\
\text { Grabbike }\end{array}$ & & 4.19 & & 3.77 \\
\hline & 3 & $\begin{array}{l}\text { Saya puas dengan kualitas } \\
\text { pelayanan yang diberikan oleh, }\end{array}$ & & 4.23 & & 3.89 \\
\hline
\end{tabular}

Berdasarkan tabel 1 diatas bahwa persepsi konsumen terhadap kualitas pelayanan Go-Ride dan Grabbike, memiliki rata-rata jawaban responden Go-Ride dan Grabbike termasuk dalam kategori yang baik, dimana nilai rata-rata tertinggi pada GoRide adalah dimensi jaminan dan empati dengan nilai 3.7566667 ,dan nilai rata-rata tertinggi pada Grabbike adalah dimensi jaminan dengan nilai 3.7166667. Sedangkan nilai rata-rata terendah pada Go-Ride pada dimensi daya tangkap dengan nilai 3.666667 dan nilai rata-rata terendah pada Grabbike pada dimensi fasilitas fisik dengan nilai 3.648333. Berdasarkan tabel diatas juga dapat kita lihat bahwa nilai ratarata tertinggi pada dimensi kepuasan konsumen adalah Go-Ride dimana dengan nilai rata-rata 4.17 ,sedangkan Grabbike hanya dengan nilai rata-rata 3.813333.

\section{Uji Validitas}

Uji validitas dilakukan untuk menguji keabsahan setiap item penyataan untuk mengukur variabel penelitian. Nilai validitas diindikasikan dengan nilai r-hitung atau nilai corrected item-total correlation hasil output SPSS pada masing-masing penyataan. Item pernyataan dianggap valid jika nilai r-hitung lebih besar atau sama dengan nilairtabel atau $r_{\alpha}$. Nilai $r_{\alpha}$ pada untuk n:100 atau df(n-2) adalah 0,197.

Tabel 1. Hasil Uji Validitas

\begin{tabular}{lllll}
\hline VARIABEL & ITEM & $\begin{array}{l}\text { R-HITUNG } \\
\text { GOJEK }\end{array}$ & $\begin{array}{l}\text { R-HITUNG } \\
\text { GRAB }\end{array}$ & KET \\
\hline KUALITAS & 1 & .619 & .465 & Valid \\
PELAYANAN & 2 & .671 & .526 & Valid \\
\cline { 2 - 5 } Tangibles) & 3 & .661 & .524 & Valid \\
\cline { 2 - 5 } & 4 & .694 & .559 & Valid \\
\cline { 2 - 5 } & 5 & .669 & .579 & Valid \\
\cline { 2 - 5 } & 6 & .685 & .483 & Valid \\
\hline KUALITAS & 1 & .695 & .624 & Valid \\
(Reliability) & 2 & .695 & .625 & Valid \\
\cline { 2 - 5 } & 3 & .697 & .592 & Valid \\
\cline { 2 - 5 } & 4 & .711 & .631 & Valid \\
\cline { 2 - 5 } & 5 & .685 & .579 & Valid \\
\hline
\end{tabular}




\begin{tabular}{lllll}
\hline KUALITAS & 1 & .684 & .570 & Valid \\
\cline { 2 - 5 } $\begin{array}{l}\text { PELAYANAN } \\
\text { (Responsiveness) }\end{array}$ & 2 & .741 & .682 & Valid \\
\hline KUALITAS & 1 & .736 & .554 & Valid \\
\cline { 2 - 5 } PELAYANAN & 2 & .651 & .617 & Valid \\
\cline { 2 - 5 } (Assurance) & 3 & .771 & .684 & Valid \\
\hline KUALITAS & 1 & .694 & .659 & Valid \\
\cline { 2 - 5 } $\begin{array}{l}\text { PELAYANAN } \\
\text { (Empathy) }\end{array}$ & 2 & .591 & .447 & Valid \\
\hline KEPUASAN & 3 & .681 & .462 & Valid \\
KONSUMEN & 1 & .515 & .727 & Valid \\
\cline { 2 - 5 } & 2 & .625 & .802 & Valid \\
\hline
\end{tabular}

Sumber : Data Primer yang diolah, Juli 2020

\section{Uji Reliabilitas}

Uji reliabilitas dilakukan untuk mengukur kemampuan/kehandalan instrumen dalam mengukur variabel yang diteliti. Reliabilitas diukur menggunakan formulasi Cronbach's Alpha dengan kaidah jika nilainya lebih besar daripada 0,6, maka instrumen yang digunakan bersifat reliabel atau handal. Sebaliknya jika nilai Cronbach's Alpha lebih kecil daripada 0,6, maka instrumen dianggap tidak valid.

Tabel 2. Hasil Uji Reliabilitas

\begin{tabular}{cccc}
\hline Variabel & $\begin{array}{c}\text { Cronbach's } \\
\text { Alpha GOJEK }\end{array}$ & $\begin{array}{c}\text { Cronbach's } \\
\text { Alpha GRAB }\end{array}$ & Ket. \\
\hline $\begin{array}{c}\text { Kualitas } \\
\text { Pelayanan }\end{array}$ & .957 & .925 & Reliabel \\
\hline $\begin{array}{c}\text { Kepuasan } \\
\text { Konsumen }\end{array}$ & .757 & .870 & Reliabel \\
\hline
\end{tabular}

Sumber : Data Primer yang diolah, Juli 2020

\section{Hasil Uji Beda Kualitas Pelayanan dan Kepuasan Konsumen}

Tabel 2. Hasil Uji Beda Kualitas Pelayanan dan Kepuasan Konsumen

\begin{tabular}{cccc}
\hline Uji Beda & t-hitung & Sig.(2-tailed) & Ket. \\
\hline $\begin{array}{c}\text { Kualitas Pelayanan } \\
\text { Go-Ride dan Grabbike }\end{array}$ & .609 & .544 & Tidak Berpengaruh Signifikan \\
\hline $\begin{array}{c}\text { Kepuasan Konsumen } \\
\text { Go-Ride dan Grabbike }\end{array}$ & 3.726 & .000 & Berpengaruh Signifikan \\
\hline
\end{tabular}

Sumber : Data Primer yang diolah, Juli 2020

Berdasarkan pada tabel 2 diatas dapat dilihat bahwa hasil uji t pada Kualitas Pelayanan Go-Ride dan Grabbike menunjukkan bahwa nilai t-hitung sebesar 0.609 dengan nilai p sebesar 0,544. Karena nilai p > 0.05 ,maka dapat disimpulkan bahwa Kualitas Pelayanan Go-Ride dan Kualitas Pelayanan Grabbike tidak berpengaruh signifikan yang artinya Kualitas Pelayanan Go-Ride tidak memiliki perbedaan 
terhadap Kualitas Pelayanan Grabbike.

Pada tabel 2 diatas terlihat juga bahwa hasil uji t pada Kepuasan Konsumen GoRide dan Grabbike menunjukkan nilai t-hitung sebesar 3.726 dengan nilai p sebesar 0,000. Karena nilai $\mathrm{p}<0.05$, maka dapat disimpulkan bahwa Kepuasan Konsumen Go-Ride dan Kepuasan Konsumen Grabbike berpengaruh signifikan yang artinya Kepuasan Konsumen Go-Ride memiliki perbedaan terhadap Kepuasan Konsumen Grabbike.

\section{Pembahasan}

Penelitian menemukan tidak adanya perbedaan yang signifikan antara kualitas pelayanan Gojek (Go-Ride) dan Grab (Grabbike) . Meskipun Gojek memiliki nilai ratarata tertinggi tetapi keduanya tetap memiliki Kualitas Pelayanan yang setara, dimana Kualitas Pelayanan dari segi Fasilitas Fisik (Tangible) seperti driver memberikan helm dan masker, driver berpakaian dengan rapi saat melakukan pelayanan, jaket yang digunakan driver tidak berbau, penampilan driver bersih driver menggunakan sepatu saat melakukan pelayanan, dan kendaraan yang digunakan layak pakai. Dari segi keandalan (reliability) GoJek dan Grab, contohnya seperti driver go-ride/grabbike selalu tersedia pada saat dibutuhkan, driver memberikan layanan tepat waktu, ada pemberitahuan dengan jelas, apabila terjadi keterlambatan, driver mengemudi dengan menaati peraturan lalu lintas, driver mengenakan harga sesuai dengan tarif yang tertera di aplikasi, driver mengantarkan konsumen ke tempat tujuan dengan akurat, dan beroperasi selama 24 jam. Dari segi daya tanggap (responsiveness) gojek dan grab,contohnya seperti driver mengonfirmasi order dengan menghubungi konsumen, untuk memastikan pemesanan dan tempat, driver segera datang setelah menerima pesanan melalui aplikasi, dan driver cepat dalam menanggapi keluhan pelanggan. Dari segi jaminan (assurance) Gojek dan Grab, contohnya seperti driver dapat mengemudikan sepeda motor dengan baik, driver mempunyai pengetahuan mengenai informasi jalan/alamat yang akan dituju, dan tersedia layanan pengaduan pada aplikasi. Dari segi empati (empathy) Gojek dan Grab, contohnya driver memberitahukan tentang penggunaan helm yang benar kepada konsumen, driver membantu pelanggan dalam mengangkat barang, dan driver sopan dan ramah dalam melakukan pelayanan.

Selain itu penelitian juga menemukan adanya perbedaan yang signifikan antara kepuasan konsumen Gojek (Go-Ride) dan Grab (Grabbike). Gojek memiliki nilai ratarata tertinggi sehingga dapat disimpulkan bahwa pada Kepuasan Konsumen Gojek lebih tinggi di bandingkan Grab. Kepuasan konsumen dapat dilihat dari perilaku konsumen setelah menggunakan Gojek atau Grab contohnya seperti konsumen tersebut merasa kualitas pelayanan yang diberikan sesuai dengan apa yang konsumen harapkan, konsumen merasa manfaat yang diperoleh sesuai dengan tarif harga yang konsumen bayarkan pada Go-ride/ Grabbike, dan konsumen puas dengan kualitas pelayanan yang diberikan oleh Gojek/Grab. 


\section{Penutup \\ Kesimpulan}

Berdasarkan hasil analisis dan pembahasan, maka dalam penelitian ini dapat disimpulkan bahwa tidak terdapat perbedaan yang signifikan antara Kualitas Pelayanan Go-Ride dan Kualitas Pelayanan Grabbike, sehingga dari segi fasilitas fisik, segi keandalan, segi daya tanggap, segi jaminan, serta segi empati menunjukkan tidak adanya perbedaan yang signifikan, dikarenakan memang untuk gojek dan grab ratarata memiliki standart yang sama dari segi kualitas pelayanan untuk para konsumennya.

Dari penelitian ini juga terdapat perbedaan yang signifikan antara Kepuasan Konsumen Go-Ride dan Kepuasan Konsumen Grabbike, terdapat kepuasan konsumen Gojek lebih tinggi di bandingkan konsumen Grab karena merasa kualitas pelayanan yang diberikan sesuai dengan apa yang konsumen harapkan, konsumen merasa manfaat yang diperoleh sesuai dengan tarif harga yang konsumen bayarkan pada Goride/ Grabbike, dan konsumen puas dengan kualitas pelayanan yang diberikan oleh Gojek/Grab.

\section{Saran}

Berdasarkan hasil penelitian ini, penulis ingin memberikan saran untuk pihak perusahaan dan peneliti selanjutnya sebagai bahan pertimbangan, yaitu untuk pihak perusahaan Gojek dan Grab menurut konsumen kualitas pelayanan Go-Ride dan Grabbike sudah termasuk dalam kategori baik setelah diukur rata-rata skor tiap dimensi kualitas pelayanan, akan tetapi untuk Go-Ride dari dimensi segi daya tanggap memiliki rata-rata paling rendah diantara dimensi lainnya, sehingga disarankan untuk pihak Gojek untuk lebih memperketat seleksi penerimaan driver baru dengan menguji daya tanggap driver atau melakukan pelatihan-pelatihan untuk para driver agar meningkapkan daya tanggapnya dalam melayani konsumen. Serta untuk Grabbike dari segi fasilitas fisik memiliki rata-rata paling rendah dari pada segi dimensi lainnya, sehingga disarankan untuk pihak Grab memberitahu para driver agar mematuhi segala fasilitas terutama menyediakan masker untuk konsumen, serta memberikan sanksi tegas dalam hal standar berpakaian agar penumpang merasa nyaman.

Untuk peneliti selanjutnya, dikarenakan dalam penelitian ini yang di teliti hanyalah terbatas sedangkan aspek-aspek yang dapat menjadi tolak ukur untuk Kualitas Pelayanan dan Kepuasan Konsumen belum semua di bahas, oleh karena itu bagi peneliti selanjutnya dapat membahas aspek-aspek lain yang belum di teliti dalam penelitian ini.

\section{Ucapan Terima Kasih}

Terima Kasih tim peneliti ucapkan kepada Yayasan Pendidikan Nasional Tridinanti (YPNT) yang telah mendukung moril. 
Kemenristekdikti atas bantuan dana Penelitian PDP Tahun Anggaran 2020 Tanggal 27 Juli 2020.

\section{Referensi}

Alatas, Salim. 2013. Dampak Konvergensi Media Terhadap Akulturasi Budaya Lokal. Makalah Konferensi Nasional Komunikasi. Departemen Ilmu Komunikasi Universitas Indonesia, 13-14 November 2013. Jakarta : UI.

Bachtiar. (2011). Analisa Faktor-Faktor yang Mempengaruhi Kepuasan Mahasiswa dalam Memilih Politeknik Sawunggalih Aji Purworejo. Dinamika Sosial Ekonomi Vol 7 No. 1.

Danang, Sunyoto. 2012. Manajemen pemasaran.Yogyakarta: Buku Seru.

Ghozali, Imam. 2011. Aplikasi Analisis Multivariat Dengan Program SPSS. Semarang : Badan Penerbit Universitas Diponegoro.

https://economy.okezone.com/read/2019/07/11/320/2077413/hasil-riset-gojekjadi-e-commerce-yang-paling-diminati?page=1 (Diakses pada 23 September 2019)

Kotler, Philip and Gary Amstrong. (2016). Prinsip-prinsip Pemasaran. Edisi13. Jilid 1. Jakarta:Erlangga.

Kotler, Philip and Kevin Lane Keller, 2016. Marketing Managemen, 15th Edition, Pearson Education,Inc

Lumintang Intan Sintya,dkk. (2018) Pengaruh Harga dan Kualitas Layanan Terhadap Kepuasan Pelayanan Jasa Transportasi Go-jek Online Pada Mahasiswa Feb Unsrat Manado. Jurnal EMBA, 6(3), 1778-1787.

Lupiyoadi, Rambat. 2013. Manajemen Pemasaran Jasa Berbasis Kompetensi(Edisi 3). Jakarta: Salemba Empat.

Mardikawati, W., \& Farida, N. (2013). Loyalitas Pelanggan , Melalui Kepuasan Pelanggan Pada Pelanggan Bus Efisiensi ( Studi PO Efisiensi Jurusan YogyakartaCilacap ). Jurnal Administrasi Bisnis, 2(1), 64-75.

Nurgiyantoro, Burhan. 2013. Teori Pengkajian Fiksi. Yogyakarta: Gadjah Mada University Press.

Tjiptono, F danG.Chandra. (2011). Service, Quality,danSatifaction. Yogyakarta: ANDI.

Zeithaml, Valerie A., Leonard Berry, and A. Parasuraman. 1996. The Behavioral Consequence Of Service Quality. Journal of Marketing, vol. 60.

Zulmianita Putuhena \& Andi Faisal Bahari, (2019). Analisis Pengaruh Kualitas Layanan Terhadap Kepuasan Konsumen Jasa Angkutan Online (GrabCar) Di Kota Makassar, 2(1). 